\title{
KESULITAN GURU DALAM PEMBELAJARAN DARING MASA COVID-19 PADA KELAS IV DI MIS MANDE KOTA BIMA
}

\author{
Emi Ermawati, Umar, Taman Firdaus, Aidin
}

IAI Muhammadiyah Bima, STKIP Al-Amin Dompu

Email: emiermawati@gmail.com., laodeumarpgmi@gmail.com tamanfirdaus@gmail.com, aidinstaialamin@gmail.com

\begin{abstract}
Abstrak:
Penelitian ini bertujuan untuk mendeskripsikan tentang kesulitan guru dalam pembelajaran daring pada kelas IV masa Covid-19 di MIS Mande Kota Bima. Penelitian ini dilakukan menggunakan pendekatan kualitatif dengan sumber data para guru wali kelas dan kepala sekolah. Tehnik pengumpulan data yang digunakan dalam penelitian ini dilakukan dengan tekni wawancara, observasi dan dokumenatsi objek penelitian. Analisis data penelitian diolah secara naratif meliputi tahap reduksi data, data display dan penarikan kesimpulan. Hasil penetilitian menunjukan bahwa guru kelas IV di MIS Mande Kota Bima mengalami berbagai kesulitan ketika menerapkan pembelajaran daring, diantaranya fasilitas tidak memadai dalam proses pembelajaran daring, peserta didik kesulitan mempelajari dan memahami materi yang banyak dalam waktu yang relatif singkat. Adapun faktor penghambat pelaksanaan pembelajaran yang dihadapi guru kelas IV di MIS Kota Bima seperti; kurangnya kuota internet sehingga pembelajaran daring tidak tercover dengan baik, peserta didik merasa jenuh selama pelajaran daring, peserta didik merasa sulit untuk mengakses internet, dan sebagian besar peserta tidak memiliki aplikasi WhatsApp sebagi penunjang pembelajaran daring. Selanjutnya untuk meminimalisir kesulitan yang dihadapi guru dalam pelaksaan pembelajaran daring pada kelas IV di MIS Mande Kota Bima, pihak sekolah dan guru melakukan beragaam upaya sederhana seperti membagun 5 TPA di setiap lingkungan agar bisa menjangkau peserta didik, melakukan kunjungan di berbagai rumah murid yang dapat di jangkau, dan membagikan kopian setiap mata pelajaran.
\end{abstract}

Kata Kunci: Kesulitan Guru, Pembealajaran Daring, Covid-19.

\section{PENDAHULUAN}

$\mathrm{P}$ endidikan abad 21 ditandai dengan adanya era revolusi industri 4.0 yang dikenal dengan abad keterbukaan dan globalisasi pada lini masa yang ditandai dengan pesat kemajuan Teknologi Informasi dan Komunikasi (TIK). Munculnya berbagai macam platform digital menjadi ruang akses informasi dan komunikasi dalam kehidupan sehari-hari (Yanti, 2020: 62). Kehadiran Teknologi Informasi dan Komunikasi juga tidak memberi pilihan lain dalam dunia pendidikan di 
tengah pandemi Covid-19. Pada akhirnya pemerintah Indonesia harus mengambil keputusan dan kebijakan yang pahit yaitu menutup sekolah untuk mengurangi kontak secara masif. Sehingga memaksa pemerintah untuk mendukung proses belajar mengajar jarak jauh. Perubahan mendadak dari metode tatap muka di ruangan kelas menjadi pembelajaran jarak jauh di rumah menjadi tantangan bagi guru agar proses pembelajaran tetap berjalan (Dewi, 2020: 56).

Guru menjadi unsur penting dalam pendidikan yang bertugas dalam melaksanakan dan mengelola serta pelayanan teknis untuk menunjang proses pendidikan (Umar, 2019). Sehingga guru harus memiliki stategi dalam melaksanakan dan mengelola pembelajaran di tengah pandemik sebagai keberlangsungan transformasi ilmu. Guru dituntut sebisa mungkin menjangkau murid-muridnya agar bisa tejadinya proses pembelajaran (Dani, 2013). Hal ini membuat guru memanfaatkan perkembangan teknologi informasi dan komunikasi (TIK) sebagai alterntif terhadap proses pengajaran dan pembelajaran untuk meningkatan tercapainya tujuan pendidikan (Lailatul, 2019: 20).

Salah satu pemanfaatan TIK dalam bidang pendidikan yaitu munculnya pembelajaran yang sering disebut sebagai e-learning atau pembelajaran elektronik. Dari istilah e-learning kemudian berkembang lagi menjadi online learning atau pembelajaran Daring. Dengan demikian pendidikan harus relevan dengan perkembangan jaman agar tujuan pendidikan dapat tercapai secara maksimal (Hastomo, 2013). Online learnig atau pembelajaran daring bertujuan memberikan layanan belajar mengajar bermutu dalam jaringan (daring) yang bersifat masif dan terbuka untuk menjangkau peserta didik dalam jangkauan luas (Sofyana, 2019). Pembelajaran daring digunakan untuk membantu pendidik dalam pemberian materi pembelajaran, mengembangkan proses interaksi dan mengfasilitasi proses pembelajaran pada peserta didik dalam jarak jauh (Budiman, 2020).

Model pembelajaran daring merupakan pola pembelajaran pilihan guru dalam merencanakan proses belajar yang sesuai dan efesien guna mencapai tujuan pembelajaran dengan memanfaatkan jaringan komputer dan internet. Dengan pembelajaran daring ini diharapkan guru tidak perlu meninggalkan kewajiban mengajar di sekolah karena guru dapat melaksanakan pembelajaran setiap saat di luar jadwal mengajar (Awaludin, 2018). Meski demikian, dalam pelaksanaanya tentu terdapat kendala atau kesulitan yang dihadapi oleh guru, banyak varian masalah 
yang menghambat terlaksananya efektivitas pembelajaran daring. Perubahan kegiatan pembelajaran yang awalnya secara tatap muka dan ditentukan jadwalnya oleh sekolah, kini guru dan siswa harus menjadwalkan sendiri agar dapat dilaksanakan dengan maksimal. Selain itu pelaksanaan pembelajaran daring mengalami keterbatasan dalam penggunaan aplikasi maupun minimnya alat dan kuota dalam pembelajaran daring. Hal ini menjadi kendala untuk melaksanakan pembelajaran daring secara maksimal. Kondisi ini juga yang dialami oleh para guru dan siswa MIS Mande Kota Bima (Farida, 2020).

Berdasarkan hasil wawancara awal peneliti dengan para guru di MIS Mande Kota Bima mengenai proses pelaksanaan pembelajaran daring tersebut. Oleh karena itu peneliti berfokus terhadap permasalahan yang dialami oleh guru dalam pelaksaan pembelajaran daring. Melalui kegiatan analisis terhadap kesulitan-kesulitan yang dialami para guru memungkinkan adanya solusi yang tepat dan terbaik dalam menunjang pembelajaran daring. Dari paparan yang telah diuraikan di atas, maka peneliti akan melakukan penelitian studi kasus dengan judul "Kesulitan Guru Dalam Pembelajaran Daring Masa Covid-19 Pada Kelas IV Di MIS Mande Kota Bima".

\section{TINJAUN TEORITIS}

\section{Makna Etimologis Profesi Guru}

Secara etimologi, dalam bahasa Inggris di temukan beberapa kata yang lazim maknanya di sebut guru, yaitu; teacher, tutor, instruktor, dan educator. Berdasarkan penjelasan Kamus Webster's, teacher diartikan seseorang yang mengajar; tutor diartikan seorang guru yang memberikan pengajaran terhadap peserta didik; instructor diartikan seorang yang mengajar; dan educator, diartikan dengan seseorang yang mempunyai tanggung jawab pekerjaan mendidik yang lain. Sedangkan dalam Kamus Besar Bahasa Indonesia, guru dipersepsikan sebagai orang yang pekerjaannya (mata pencahariannya) mengajar (Umar, 2019).

Guru sering pula di konotasikan sebagai kepanjangan dari kata “digugu dan ditiru". Digugu artinya segala sesuatu yang disampaikan oleh guru senantiasa dipercaya, di dengar, diikuti, dan diyakini sebagai sebuah kebenaran oleh semua muridnya, sedangkan ditiru arinya seorang guru menjadi suri tauladan bagi semua muridnya, mulai dari cara berpikir, cara berbicara, hingga cara berprilaku sehari-hari, dengan kata lain figur guru harus menjadi contoh. Ungkapan lain tentang guru juga 
dikenal dengan sebuah pribahasa yang berbunyi "guru kencing berdiri, murid kencing berlari”. Pribahasa tersebut memiliki makna bahwa semua perilaku guru menjadi panutan bagi anak didiknya (Umar, 2019).

Dari berbagai penjelasan di atas, dapat disimpulkan bahwa pengertian guru sesungguhnya memuat beberapa hal pokok yaitu:

a. Guru dari segi kebahasaan cenderung ditafsirkan sebagai seorang pendidik yang pekerjaannya mengajar, mendidik, melatih orang lain dengan keahlian dan pengetahuan yang dimilikinya sehinga menjadi sumber penghidupan bagi dirinya.

b. Guru dari segi istilah menitikberatkan kepada pribadi seseorang dengan segala kapasitas dan tanggung jawabnya untuk menididik orang lain dalam mengembangkan potensi dalam dirinya, mulai dari potensi kognitifnya, psikomotorik, dan afektifnya sehingga menjadikan orang tersebut lebih terarah dan bermanfat dalam kehidupan sosial masyarakat.

c. Guru umumnya didefinisikan sebagai figur manusia dewasa yang dengan ilmunya ia dapat mengajara, mendidik, membimbing, dan mengarahkan manusia lainnya yang bermuara pada perbaikan aspek jasmani dan rohaninya.

d. Guru dalam konteks pandangan Islam dipahami sebagai bentuk pencerminan sifat-sifat kebaikan dalam diri manusia yang kaitannya dengan praktik mengajar dan pemberi pentunjuk bagi perbaikan perilaku manusia lainnya (Umar, 2019).

\section{Tugas Profesional Seorang Guru}

Guru senantiasa dihadapkan dengan tugas pokok yang harus dilaksanakan sebagai konsekuensi dari aktivitas profesinya. Hal ini termuat dalam deskripsi Undang-Undang RI Nomor 20 Tahun 2003 tentang sistem pendidikan Nasional (UU Sisdiknas) BAB XI, Pasal 39 menyebutkan bebera ha antara lain; (1) menempatkan guru sebagai unsur tenanag kependidikan pengawasan, dan pelayanan teknis untuk menunjang proses pendidikan pada satuan pendidikan. (2) menegaskan guru sebagai pendidik profesional yang bertugas merencanakan, melaksanakan proses pembelajaran, menilai hasil belajar, melakukan pembimbingan dan pelatihan, bagi peserta didiknya. Secara terperinci dijelaskan pula dalam Undang-Undang RI Nomor 14 Tahun 2005 tentang Guru dan Dosen BAB I, Pasal 1 juga menyatakan bahwa guru sebagai pendidik profesional memiliki tugas utama mendidik, mengajar, 
membimbing, mengarahkan, melatih, menilai, dan mengevaluasi peserta didik pada pendidikan usia dini jalur pendidikan formal, pendidikan dasar, dan pendidikan menengah (Umar, 2019).

Muhammad Mustari dalam Umar juga menjabarkan tugas seorang guru yang mengacu pada rumusan Pembinaan Pendidik dan Tenaga Kependidikan (P2TK) Direktorat Jendral Pendidikan Tinggi Departemen Pendidikan Nasional, bahwa yang harus dilakuakn oleh guru sebagi pekerja professional yaitu:

a. Guru sebagai pendidik yang mengembangkan potensi dasar peserta didik, mengembangkan kepribadian peserta didik, memberikan keteladanan, dan menciptakan suasana pendidikan yang konduksif.

b. Guru sebagai pengajar yang berfungsi membuat perencanaan pembelajaran, melaksnakan pembelajaran yang mendidik, dan menilai proses serta hasil pembelajaran.

c. Guru sebagi pembimbing berfungsi mendorong berkembangnya perilaku positif dalam pembelajaran, mendiagnosis permasalahan peserta didik, dan membimbing peserta didik dalam memecahkan masalah pembelajaran.

d. Guru sebagai pelatih berfungsi melatih keterampilan-keterampilan yang diperlukan dalam pembelajaran dan membiasakan peserta didik berprilaku positif dalam pembelajaran.

e. Guru sebagai pengembang program berfungsi membantu mengembangkan dan melaksankan program kurikulum disekolah, serta membantu mengembangkan program pendidikan sekolah dan membantu pengembangan program pendidikan sekolah dan hubungan kerja sama antara sekolah.

f. Guru Sebagai pengelola program yang berfungsi membantu secara aktif dalam menjalin hubungan kerja sama antara sekolah dan masyarakan, serta membantu membangun iklim dan program pendidikan di sekolah yang bersentuhan langsung dengan kehidupan masyarakat.

g. Guru sebagai tenaga professional yang berfungsi melakukan upayaupaya untuk menigkatkan kemampuan professional (Umar, 2019).

Dalam konsep pendidikan Islam, gambaran berkenaan tentang tugas guru dikemukakan oleh Imam Ghazali menyebutkan seorang guru "mursyid mengajar" memiliki tugas di antaranya: 1) Memberikan kasih sayang pelajar dan menganggapnya seperti anak. 2) Melakukan pengajaran tanpa imbalan sebagaimana keteladanan. 3) Tidak 
menyimpan sesuatu nasehat bagi hari esok seperti melarangnya dari mencari kedudukan sebelum patut memperolehnya serta melarangnya belajar ilmu yang tersembunyi sebelum menyempurnakan ilmu yang terang. Dan 4) Memberikan nasehat kepada pelajar serta melarang dari ahlak tercela, bukan dengan penegasan penghilangan kewibawaan serta patutlah dia untuk bersikap lurus, lalu menuntutnya pula dengan bersikap yang lurus.

Dengan demikain, dipahami bahwa guru merupakan tingkatan profesi yang digelutu seseorang yang merupakan bagi dari pekerjaan profesional yang berusaha mengarahkan, menguyakan mencerdasakan kemampuan pengetahuan manusi lainnya dengan jalan pengajaran, pendidikan, pelatihan, serta pembimbingan melalui metode pembelaran yang berguna bagi kehidupannya di masa depan. Pada akhirnya menjadikan sesesorang menjadi manusia yang berdaya saing, berdayaguna, dan memiliki moral yang baik dalam lingkungan kehidupan keluarga dan sosial mamsyarakat.

\section{Konsep Dasar Pembelajaran Daring}

Pembelajaran online atau disebut juga pembelajaran daring adalah pembelajaran jarak jauh (PJJ). Sistem pembelajaran jarak jauh merupakan sistem yang sudah ada sejak pertengahan abad 18. Sejak awal, pembelajaran jarak jauh selalu menggunakan teknologi untuk pelaksanaan pembelajarannya, mulai dari teknologi paling sederhana hingga yang terkini. Secara singkat, sejarah perkembangan pembelajaran jarak jauh dapat dikelompokkan berdasarkan teknologi dominan yang digunakannya.

Menurut Michael sebagaiman dijelaskan oleh Nurhayati (2020) bahwa pembelajaran E-learning atau pembelajaran daring yang disusun ialah dengan tujuan menggunakan suatu sistem elektronik atau juga komputer sehingga mampu untuk mendukung suatu proses pembelajaran. Sedangkan menurut Chandrawati E-learning adalah suatua proses pembelajaran jarak jauh dengan cara menggabungkan prinsip-prinsip didalam proses suatu pembelajaran dengan teknologi (Nurhayati, 2020). Lebih lanjut, menurut Taylor dalam Julaiha (2020) mengungkapkan bahwa dalam pelaksanaan pendidikan jarak jauh (PJJ) TIK telah melampau lima generasi, sebagai berikut: 
a. Model korespondensi pelaksanaan pembelajaran PJJ didasarkan pada teknologi cetak (print). Bahan ajar yang di sampaikan kepa peserta di disajikan dalam bentuk tercetak.

b. Model multi media model ini di dadasarkan pada teknologi, cetak, audio, dan vidio.

c. Model tele-learning generai ini di tandai dengan penerapan teknologi tele komunikasi untuk menyediakan kesempatan melakukan komunikasi.

d. Model pembelajaran fleksibel model ini di dadasarkan pada penyampaian online melalui internet secara pasif.

e. Model pembelajaran fleksibel yang lebih cerdas (the intelligent flexsible learning model) model generasi ini merupakan kelanjutan dari generasi keempat, yang lebih berorientasi pada pemanfaatan keistemewaan internet dan jaringan (web).

f. Generasi keenam, generasi ketiga el-learning pada generasi ini di kembangkan lingkungan belajar yang lebih kolaboratif yang didasarkan pada epistimologi kontruktivisme yang mendorong praktek refleksi melalui alat-alat seperti e-portfolio dan onlinecommunities.

Perkembangan pembeljarannya daring, istilah PTJJ saat ini lebih populer dimasyarakat seperti ele-learning, online learning dan mobile learning yang lebih memasyarakatkan lebih fenomena PJJ. Seperti disebutkan, pembelajaran online lahir mulai generasi keempat setelah adanya internet. Jadi pembelajaran online adalah pembelajaran yang dilakukan melalui jaringan internet. Oleh karena itu, dalam bahasa indonesia pembelajaran online diterjemahkan sebagai pembelajaran dalam jaringan atau pembelajaran daring. Istilah online learning banyak disinonimkan dengan istilah lainya seperti ele-learning, internet learning, web-based learning, tele-learning, distributed learning dan lain sebagainya. Dalam beberapa tahun terakhir, pembelajaran online juga sering dikaitkan dan digunakan sebagai pandangan istilah mobile learning atau m-learning, bergerak (mobile communication devices) seperti komputer tabel dan smart phone.

Pembelajaran learning tidak sekedar membagikan materi pembelajaran dalam jaringan internet. Dalam online learning, selain ada materi pembelajaran online juga ada proses kegiatan belajar mengajar secara online. Jadi perbedaan pokok antara pembelajaran online denga sekedar materi pembelajaran online adalah adanya interaksi selama 
proses pembelajaran. Interaksi dalam pembelajaran terdiri dari interaksi antara pembelajaran dengan pengajaran atau fasilitor, dengan sesama pembelajaran lainya, dan dengan materi pembelajarannya itu sendiri. Ketiga jenis interaksi yang terjadi dalam pembelajaran online itulah yang akan menciptakan pengalaman belajar (Belawati, 2019). Dengan demikian, pemaknaan pemebelajaran daring sesungguhnya dapat dipahami sebagai proses pembelajaran jarak jauh yang memanfaat perangkat/media teknologi inforamasi dan komunikasi sebagai sarana pembelajaran yang memungkinkan danya hubungan timbal balik pembelajaran antara guru dan siswa yang berada dalam situasi atau tempat yang berbeda dalam proses kegiatan pembelajaran.

\section{METODE PENELITIAN}

Jenis penelitian yang digunakan adalah penelitian kualitatif. Kualitatif adalah suatu proses penelitian yang menggunakan metodelogi yang menyelidik suatu fenomena sosial dan masalah manusia jenis penelitian ini menghasilkan data deskriptif berupa kata-kata atau lisan dari narasumber (Sugiyono, 2013). Penggunaan jenis penelitian kualitatif pada penelitian ini untuk memperoleh data dan informasi secara deskriptif terkait dengan Kesulitan Guru Dalam Pembelajaran Daring Pada Kelas IV MIS Mande Kota Bima. Adapun sumber data primer terdiri dari dua orang guru kelas IV dan kepala sekolah MIS Mande Kota Bima. Adapun tehnik pengumpulan data yang digunakan dalam penelitian ini dilakukan dengan tekni wawancara, observasi dan studi dokumenatsi pada objek penelitian. selanjutnya hasil data yang berkaitan dengan analisis kesulitan guru kelas IV MIS Mande akan diolah secara naratif melalui tahapan reduksi data, data displaiy (penyajian data) dan penarikan kesimpulan.

\section{HASIL DAN PEMBAHASAN}

\section{Bentuk Kesulitan Guru Dalam Pelaksanaan Pembelajaran Daring Pada Kelas IV di MIS Mande Kota Bima}

Penelitian ini dilaksanakan di MIS Mande Kota Bima yang beralamat di jalan Tendean nomor 11 yang berada di Mande Kecematan Mpunda Kota Bima penelitian dilaksanakan pada kelas IV. Dari hasil wawancara yang yang dilakukan oleh peneliti denga guru mengenai proses pembelajaran secara daring khususnya pada kelas IV bisa 
dikatakan tidak efektif. Karena proses pembelajaran tidak berjalan dengan baik atau lancar. Pembelajaran daring merupakan altertif guru pada saat pandemi. Dari hasil wawancara yang dilakukan peneliti pada ibu Ida Frida, S.Pd.I selaku guru wali kelas IV kesulitan yang dialami guru selama melaksanakan pembelajaran daring sangat beragam. Kesulitan datang dari fasilitas penunjang sampai aplikasi yang tidak dapat di gunakan oleh sebagian murid.

"Proses belajar mengajar di sekolah MIS Mande Kota Bima yang dilaksanakan secara daring pada masa pademi covid-19 menjadi hal yang baru dan menantang bagi kalangan guru. Jika di lihat secara sekilas, pembelajaran secara daring nampak begitu mudah namun faktanya penyelengaraan pendidikan Madrasah Ibtidayah di tengah pandemi covid-19 baik murid, guru, maupun orang tua berkeluh kesah ketidak lancaran jaringan internet. Hal ini membuat belajar mengajar dari rumah tidak bisa berjalan dengan efektif. Penggunaan aplikasi yang di gunakan dalam kegiatan pembelajaran daring seperti WhatsApp Grup membutuhkan jaringan internet yang kuat karena tanpa jaringan internet proses pembelajaran tidak dapat terlaksana dengan baik. Selain itu fasilitas yang tidak mendukung sehingga guru tidak efektif menyampaikan materi atau sistem pembelajaran daring, tentu tidak seefektif pembelajaran di sekolah. dampak lanjutanya, peserta didik akan kesulitan memahami materi yang banyak dalam waktu yang relatif singkat dan kelebihan dalam proses pembelajaran daring ini tidak ada atau kurang efektif." (Farida, 2020).

Senada dengan yang di sampaikan oleh ibu Novri zaqiyayah, S.Pd.I terkait dengan proses pembelajaran daring yang di laksanakan di sekolah MIS Mande Kota Bima bahwa,

"mengalami kesulitan dalam menggunakan aplikasi dan fasilitas yang tidak mendukung sehingga guru tidak efektif menyampaikan materi atau sistem pembelajaran daring dan tentu tidak seefektif pembelajaran di sekolah. Beliau menggukapkan bahwa proses pembelajaran daring ini tidak terlaksana dengan baik karena banyaknya hambata-habatan yang dialami guru (Zaqiyayah, 2020).

Hasil wawancara yang dilakukan dengan guru kelas IV dan kepala MIS Mande Kota Bima tersebut dapat disimpulkan bahwa proses terjadinya pelaksanaan pembelajaran daring pada kelas IV ini tidak terlaksana dengan baik karena banyak hambatan yang dihadapi yaitu: pada penggunaan aplikasi WhatsApp guru masih banyak yang tidak bisa menggunakannya karna hanya sebagian kecil saja yang bisa menggunakan WhatsApp guru maka proses pembelajaran daring tidak terlaksana dengan baik. Kondisi ini, dikarenakan proses pembelajaran di sekolah MIS Mande Kota Bima dilaksanakan secara daring pada masa pademi covid-19, ini merupakan kali pertama bagi sekolah yang ada di wilayah Mande melaksanakan pembelajaran dengan cara yang berbeda. Pembelajaran daring ini menjadi hal yang baru kalangan guru dan pihak sekolah. Oleh karena itu semua stakeholder di MIS Mande Kota Bima 
berusaha untuk menyesuaikan keadaan ini. Namun pada faktanya penyelengaraan pembelajaran daring di MIS Mande Kota Bima di tengah pandemi covid-19 mengalami berbagai kesulitan. Adapun kesulitankesulitan yang dihadapi antara lain:

a. Fasiltas tidak memadai atau tidak mendukung sehingga proses pembelajaran daring tidak dapat dilaksanakan dengan efektif. Sehingga siswa tidak mampu menerima pelajaran dengan baik

b. Membutuhkan jaringan internet yang kuat karena tanpa jaringan internet proses pembelajaran tidak dapat terlaksana dengan baik sehinga proses pelaksanaan pembelajaran daring tidak terhambat.

c. Peserta didik akan kesulitan mempelajari dan memahami materi yang banyak selama pembelajaran daring dalam waktu yang relatif singkat.

Salah satu faktor keberhasilan dalam belajar ialah fasilitas belajar yang memadai menurut Suryasubrata untuk mencapai suatu prestasi belajar yang baik di perlukan proses belajar mengajar yang lancara, sedangkan proses belajar mengajar yang lancar harus didukung oleh lengkap tidaknya suatu fasilitas. Proses belajar mengajar akan berjalan lancar jika ditunjang oleh sarana yang lengkap, dari gedung sekolah sampai sarana yang dominan yaitu alat peraga (Muhammad, 2019: 56). Menurut teori Winata putra menyatakan hasil belajar merupakan bukti keberhasilan yang telah di capai siswa dimana setiap kegiatan belajar dapat menimbulkan suatu perubahan yang khas. Dalam hal ini belajar meliputi keterampilan proses, keaktifan, motivasi juga prestasi belajar (Edukasi, 2020).

\section{Faktor Penghambat Guru Dalam Pelaksanaan Pembelajaran Daring Pada Kelas IV MIS Mande Kota Bima}

Dalam pelaksanaan pembelajaran daring, tentu terdapat faktor yang menghambat guru maupun murid untuk menerapkannya. Kendala yang dihadapi guru dalam pembelajaran daring dikarenakan fasilitas yang tidak mendukung bagi pelaksanaan pembelajaran terutama masalah kuoata internet. Selain itu juga, faktor penghambat datang dari murid dimana sebagian murid tidak memiliki handphone untuk mengikuti pembelajaran daring

"Dalam pelaksanaan pembelajaran daring tentu banyak faktor penghambat dalam pelaksanaannya sehingga tidak evektivitas. Tidak efektifnya pembelajaran daring membawa dampak yang sangat besar terhadap peserta didik dalam proses pembelajaran yang biasanya dilaksanakan secara langsung dan secara tatap muka kini dialihkan menjadi pembelajaran dilakukan secara daring. Selama pelaksanaan pembelajaran daring, peserta didik merasa jenuh karna tidak adanya 
interaksi dengan temanya di kelas secara langsung seperti di sekolah. Selain itu, banyak peserta didik yang tidak dapat mengakses internet karena fasilitas penunjang tidak mendukung pelaksanaan pembelajaran daring. Penghambat lain yang terjadi ketika proses pelaksanaan pembelajaran diantaranya yaitu belum semua peserta didik memiliki handphone, meyebabkan sedikit juga siswa yang dapat merespon pembelajaran. Faktor-faktor kendala dalam proses pembelajaran daring ini justru menurunkan mutu pembelajaran bagi murid dan faktor penghambat guru dalam proses pelaksanaan transformasi ilmu kepada murid. Kendala yang dialmi guru terjadi ketika tidak ada kuota untuk membagikan materi, buat beli kuota perlu biaya ekstra lagi yang harus dikeluarkan. Selain kendala dari murid dan guru, faktor kendala juga berasal dari orangtua. orangtua yang sibuk bekerja sehingga mengontrol anak dalam pembelajaran daring." (Zaqiyayah, 2020).

Hal ini juga di ugkapkan oleh wali kelas IV oleh ibu Ida farida,

S.Pd.I bahwa,

"bahwa pada saat kegiatan pembelajaran daring yang dilakukan selama masa pandemi ini, banyak menemui kesulitan-kesulitan yang di hadapi oleh guru dalam proses pembelajaran daring di antaranya guru merasa kesulitan dalam membagi materi pemelajaran hal itu dikarenakan sebagian besar murid di MIS Mande tidak memiliki fasilitas berupa handphone dan kuota internet, sedikitnya murid yg mampu mersespon dan fasilitas yang menunjang tidak dapat mendukung dalam proses pelaksanaan pembelajaran daring ini. Selain itu guru mengalami kendala dalam kuoata internet maka proses pembelajaran daring terhambat dan tidak terlaksana dengan baik (Farida, 2020).

Hasil wawancara yang dilakukan dengan guru kelas IV dan kepala MIS Mande Kota Bima tersebut dapat disimpulkan bahwa proses terjadinya pelaksanaan pembelajaran daring pada kelas IV ini tidak terlaksana dengan baik karena banyaknya hambatan-hambatan yang dihadapi oleh guru seperti; ketidak adanya fasilitas berupa handphone atau kuoata internet maka proses pembelajaran daring ini tidak dapat terlaksana dengan baik. Dalam pelaksanaaan pembelajaran daring tentu tidak berjalan dengan efektif. Terdapat kendala atau hambatan dalam proses pelaksanaan pembelajaran daring yang dihadap guru maupun yang dihadapi oleh siswa. Adapun hambatan-hambatan yang dihadapi antara lain:

a. Peserta didik merasa jenuh selama melaksanakan pembelajaran karna tidak adanya kontak sosial secara langsung selama pembelajaran.

b. Sedikitnya respon yang datang dari murid selama pembelajaran daring, hal ini dikarena fasilitas yang tidak mendung bagi pelaksanaan pembelajaran daring seperti handphone sebagai alat komunikasi dalam pembelajaran daring.

c. Banyaknya peserta didik yang tidak dapat mengakses internet karna terkendala biaya dalam pembelian kuoata internet. Sehingga keadaan ini justru menurunkan mutu pembelajaran bagi siswa. 
d. Sebagian besar orangtua sibuk bekerja sehingga menyebabkan kurangnya pemantau proses pembelajaran jarak jauh yang dilakukan di rumah

e. Beberapa murid tidak memiliki aplikasi WhatsApp sebagi penunjang pembelajaran daring.

f. Kurannya kuota guru sehingga terkendala dalam membagikan materi.

Menurut Gikas \& Grant dalam Sadikin disebutkan bahawa tataran pelaksanaanya pembelajaran daring memerlukan dukungan perangkat perangkat mobile seperti smarphone atau telepon adroid, laptop, komputer, tablet, dan iphone yang dapat dipergunakan untuk mengakses informasi kapan saja dan dimana saja (Sidikin, 2020: 216).

\section{Upaya Guru Dalam Meminimalisir Kesulitan Pelaksanaan Pembelajaran Daring Pada Kelas IV MIS Mande Kota Bima}

Pembelajaran daring merupakan hal yang baru bagi MIS Mande Kota Bima, tentu terdapat kesulitan dalam menerapkan pembalajaran ini. Namun perlu upaya agar pemebalajaran tidak terhamba karena situasi ini. Dalam hal ini diperlukan cara untuk meminimalisir kesulitan yang dihadapi guru dan murid sebagai dampak dari pembelajaran daring. Upaya minimalisir ini dilakukan oleh semua pihak stakholder mulai dari guru itu sendiri sampai kepala MIS Mande Kota Bima. Hal itu bertujuan agar proses pembelajaran tidak terhenti pada saat pandemi. Adapun upaya-upaya yang dilakukan dalam meminimalisir kesulitan pelaksanaan pembelajaran daring pada kelas IV ibu Wahidah mansyur, S. Ag. selaku kepala sekolah MIS Mande Kota Bima mengatan, sebagai berikut:

"Pembelajaran daring membawa kesulitan di tengah-tengah pendidikan di MIS Mande Kota Bima dalam menyampaikan ilmu. Melihat keadaan ini tentu guru melakukan berbagai upaya untuk meminimalisir kesulitan yang terjadi dalam pembelajaran daring. guru membagun lima TPA di setiap lingkungan mande sebagai pos-pos anak untuk belajar. Guru melakukan kunjungan di berbagai rumah rumah murid yang dapat di jangkau oleh guru yang mengalami kendala fasilitas. Tindakan lain yang dilakukan guru yaitu membagikan kopian setiap mata pelajaran agar anak tidak ketinggal materi pembelajaran. Kepala sekolah memutuskan untuk membagikan paket untuk guru-guru guna terlaksananya proses pembelajaran daring sehingga memungkinkan murid dan guru melaksanakan proses belajar mengajar dari rumah masing-masing. Alternatif lain yang dilakuakn pihak sekolah ketika pembelajaran darin tidak dapat berjalan efekti maka murid disuruh datang ke sekolah sesuai dengan jadwal yang telah ditentukan oleh sekolah" (Mansyur, 2020).

Berdasarkan wawancara yang dilakukan dengan guru dan kepala MIS Mande Kota Bima, mengatakan bahwa proses terjadinya perlaksanan pembelajaran daring ini tidak terlaksana dengan baik karna 
banyak hambatan yang dihadapi. Diantaranya yaitu banyaknya keluh kesah yang datang dari orangtua murid yang tidak mampu mengurus anaknya ketika pembelajaran daring berlangsung dikarenakan sibuk bekerja sehingga kepala sekolah memutuskan untuk membagikan kelompok tiap-tiap lingkungan di MIS Mande atau membagun TPA sehingga dapat menjakau keberadaan murid. Selain itu, guru pun merasakan kesulitan dalam proses pembeajaran daring ini berlangsung dalam mebagikan materi karena terhalang oleh kuota internet maka kepala sekolah memutuskan membagikan kuoata tiap-tiap guru untuk meringankan beban yang dihadapi guru. Karna ada banyakya kendalakendala dan hambata selama proses pembelajaran daring berlangsung, sehingga membuat guru dan kepala MIS Mande Kota Bima memutuskan untuk menyuruh murid datang kesekolah sesuai dengan jadwal sebagai salah satu jalan alternatif lain.

Dalam hal ini diperlukan solusi untuk meminimalisir pembelajaran daring yang kurang efektif agar proses transformasi ilmu kepada siswa tidak terhambat. Solusi-solusi ini datang dari berbagai pihak baik itu dari kepala sekolah maupun dari guru wali kelas agar terciptanya pembelajaran yang efektif di tenggah pandemi. Adapun solusi-solusinnya diantara lain:

a. Guru melakukan upaya membagun 5 TPA di setiap lingkungan, maka guru mampu menjangkau bagaimana proses pelaksanaan pembelajaran ini berlangsung di berbagai TPA yang di bagi di setiap lingkungan Mande.

b. Melakukan kunjungan di berbgai rumah murid yang dapat di jangkau oleh guru. Untuk itu guru bisa memperhatikan bagaiman cara pelaksanaan secara langsung.

c. Guru membagikan kopian setiap mata pelajaran untuk menunjang pembelajaran yang terhambat selama pandemi dan tindakan ini dilakukan karena pembelajaran daring tidak efektif .

d. Agar tidak terhambatnya proses pembelajaran daring kepala sekolah memutuskan untuk membagikan paket untuk guru-guru guna terlaksananya proses pembelajaran daring sehingga memungkinkan murid dan guru melaksanakan proses belajar mengajar dari rumah masing-masing

Menurut Stoner fungsi seorang kepala sekolah sebagai pengambil keputusan yang sulit (make difficult decisions) mengemukakan bahwa pembuatan keputusan adalah proses manusiawi yang disadari dan 
mencakup fenomena individu dan sosial, didasarkan pada premis nilai dan fakta, menyimpulkan sebuah pilihan diantara alternatif, dengan maksud bergerak menuju pada sesuatu yang diinginkan, yang membawa motor penggerak, penentu kebijakan sekolah, yang akan menentukan tujuan pendidikan pada umumnya direalisasikan. Kepemimpinan kepala sekolah yang efektif. Maka pada proses pembelajaran daring kepala sekolah memberikan kebijakan atau keputusan yaitu membagikan paket untuk guru-guru guna terlaksananya proses pembelajaran mengajar yang efektif dan efesien (Permadani, 2018).

\section{SIMPULAN}

Berdasarkan data diperoleh peneliti, pelaksanaan pembelajaran daring pada kelas IV di MIS Mande Kota Bima, dapat dikesimpulkan bahwa dalam pelaksanaan pembelajaran daring yang dilaksanakan oleh guru di kelas IV tidak efektif. Guru menemukan kesulitan-kesulitan ketika menerapkan pembelajaran daring, diantaranya Fasilitas tidak memadai atau tidak mendukung dalam proses pembelajaran daring, membutuhkan jaringan internet yang kuat, peserta didik kesulitan mempelajari dan memahami materi yang banyak dalam waktu yang relatif singkat. Adapun faktor penghambat pelaksanaan pembelajaran yang dihadapi guru dalam melaksanakan melaksanakan pembelajaran daring di kelas IV di MIS Mande Kota Bima adalah faktor yang berasal dari guru dan dari siswa itu sendiri. Faktor yang menjadi penghambat yang berasal dari guru yaitu kurangnya kuoata internet sehingga pembelajaran daring tidak tercover dengan baik. Kemudian faktor yang berasal dari siswa antara lain peserta didik merasa jenuh selama pelajaran daring, seserta didik merasa sulit untuk mengakses internet, dan sebagian besar siswa tidak memiliki aplikasi WhatsApp sebagi penunjang pembelajaran daring. Selanjutnya untuk meminimalisir kesulitan yang dihadapi guru dalam pelaksaan pembelajaran daring pada kelas IV di MIS Mande Kota Bima maka solusi yang dilakukan guru antara lain yaitu membagun 5 TPA di setiap lingkungan agar bisa menjangkau murid-murid, melakukan kunjungan di berbgai rumah murid yang dapat di jangkau, membagikan kopian setiap mata pelajaran. Solusi yang dilakukan oleh kepala sekolah adalah untuk membagikan paket kuota untuk guru-guru guna terlaksananya proses pembelajaran. 


\section{DAFTAR PUSTAKA}

Awaluddin, Yasser. (2018)."Efektifitas Program Guru Pembelajaran Dalam Meningkatkan Kompetensi Guru IPS Dengan Moda Daring Murni Dan Daring Kombinasi: Studi Evaluatif dan Komparatif", Jurnal Pendidikan Kebudayaan, No.1, Volume 3 .

Belawati, Tian. (2019) Pembelajaran Online. Tangerang Selatan: Universitas Terbuka.

Budiaman. (2010).“Analisis Faktor-Faktor Kesulitan Penerapan ELearning Dalam Pembelajaran IPS,Jurnal Sejarah Lontar, No.2, Volume 7.

Danim, Sudarman. (2013). Pedagogi Andragogi dan Heutagogi. Alfabeta:Bandung.

Dewi, Wahyu Aji Fatma. (2020). "Dampak Covid-19 Terhadap Implementasi Pembelajaran Daring di Sekolah Dasar", Jurnal Ilmu Pendidikan, Nomor.1, Volume 2.

Farida, Ida. (2020) Wawancara, Kota Bima Tanggal, 14 September.

Hastomo, Aldila Siddiq. (2013) "Efektivitas Media Pembelajaran ELearning Terhadap Prestasi Belajar Pebdidikan Agaman islam Siswa di SMA Negeri 1 Yogyakarta”. Skripsi”, Universitas Islam Negeri Sunan Kalijaga, Yogyakarta.

Lailatul, Nurul dkk. (2019) "Efektifitas Pemebelajaran Berbasis Daring:Sebuah Bukti Pada Pembelajaran Bahasa Inggris", Jurnal Tatsqif, No.1, Volume 17.

Mansyur, Wahidah. (2020) Wawancara, Kota Bima Tanggal, 14 September.

Muhamad, Havid, dkk. (2019) "Pengaruh Fasilitas Belajar Berbasis Teknologi Terhadap Prestasi Bealajar Siswa” No.1, Vol. 12.

Nurhayati, Metode Pembelajaran Daring /E-learning Yang Efektif, dalamhttps://www.researchgate.net/publication/340478043_Meto de_Pembelajaran_DaringLearning_Yang_Efektif_A_Pendahulua n_Sejarah_Elearning.

Permadani, Danang Rizky dkk. (2018). "Kepemimpinan Kepala Sekolah Dalam Pembuatan Keputusan”. No.3, Vol.1.

Sandusiyoto dkk. (2015). Dasar Metodelogi. Yogyakarta: Literasi Media Publishing.

Sidikin, Ali dkk. (2020) "Pembelajaran Daring Ditengah Wabah Covid19", No. 02, Vol. 06.

Siti Julaiha, Vitual Learning Pemanfaatan Teknologi Informasi dan Komunikasi Untuk Meningkatkan Kualitas Pembelajaran, dalam https://media.neliti.com/media/publications/220193-virtuallearning-pemanfaatan-teknologi-i.pdf, diambil pada tanggal 30 september 2020, pukul 20: 48 Wita.

Sofyana, Latjuba, dkk. (2019). "Pembelajaran Daring Kobinasi Berbasis Whatsapp Pada Kelas Karyawan Prodi Teknik Informatika Universita PGRI Madiun”, Jurnal Nasional Pendidikan Teknik Informatiak, Nomor.1, Volume 8. 
Sugiyono. (2013) Metode Penelitian Kuantitatif Kualitatif dan R\&D. Bandung: Alvabet.

Umar, U. (2019). Pengantar Profesi Keguruan. Rajawali Press.

Yanti, Minanti Tirta Yanti dkk. (2020). "Pemanfaatan Portal Rumah Belajar Kenmendikbut Sebagai Model Pembelajaran Daring di Sekolah Dasar, Jurnal Pendidikan Dasar, Nomor.1, Volume 5.

Zaqiyayah, Novri. (2020). Wawancara, Kota Bima Tanggal, 14 September. 